\title{
JUURNAL.RU
}

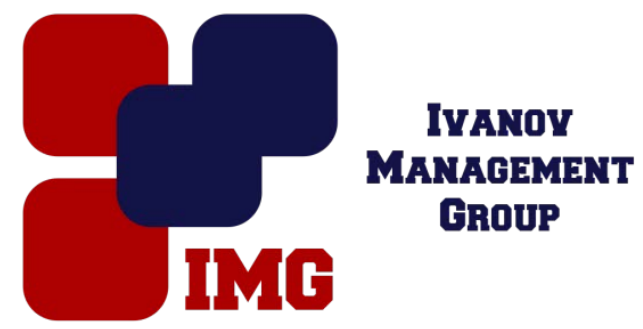

\author{
Матвеева Г.К., Милитдинова Ю.А. \\ ФГКОУ «Пермское суворовское военное училище МО РФ» \\ МАОУ «Предметно-языковая школа «ДУПЛЕКС» \\ Пермь, Россия
}

doi: 10.18411/lj-30-11-2016-1-08

idsp 000001:lj-30-11-2016-1-08

\section{Асинхронность эмбриогенеза и уровень элиминации зародышей сизой чайки}

\section{Аннотация}

Изучался темп эмбриогенеза сизой чайки в пределах одной колонии. Темп развития эмбрионов характеризуется асинхронностью. Длительность инкубации варьирует от 21 до 26 суток. Уровень элиминации зародышей в колонии достигает 6, 6 \%. Наиболее критический период эмбриогенеза приходится на первые сутки. Гетерохронии эмбрионального развития у сизой чайки проявляются не только в пределах одной кладки, но и в пределах всей микропопуляции (колонии острова), что обеспечивает ее фенотипическую разнородность.

Ключевые слова: темп эмбриогенеза сизой чайки, гетерохронии, асинхронность, элиминация зародышей.

\section{Annotation}

The rate of embryogenesis of the common gull was studied within the colony. The development of embryos is characterized by asynchrony. The duration of incubation ranges from 21 to 26 days. The level of elimination of embryos in the colony reaches $6,6 \%$. The most critical period of embryogenesis falls at the first day. The heterochronia of embryonic development of the common gull appears not only within the masonry, but also within the entire micropopulation (of the colony on the island), which provides its phenotypic heterogeneity.

Key words: the rate of embryogenesis of the common gull, heterochronys, asynchrony, elimination of embryos.

Среди многих проблем орнитологии проблема размножения и раннего онтогенеза птиц остается одной из центральных, так как именно в раннем онтогенезе происходят изменения, влияющие на филогенез организмов. Изучению этой проблемы посвящены многочисленные работы (Бэр, 1828; Рагозина, 1961; Гофман, 1977; Шураков, 1984; Болотников и др., 1985; Родимцев, 2004; Чугайнова, 2005). Вскрыты новые закономерности возникновения фенотипической разнородности особей в популяции, в основе которой лежит 
гетерогенность яиц, гетерохронность развития эмбрионов и птенцов. Вместе с тем, одной из открытых проблем является изучение темпа эмбриогенеза (Шураков и coавт., 2013), и, соответственно, изменение времени закладки определенного органа или структуры эмбриона (так называемые гетерохронии) у разных экологических групп птиц. В работах школы А.М. Болотникова(1985) было доказано, что темп развития зародышей даже в одной кладке неодинаков: он выше у зародышей из последних яиц кладки по сравнению с первыми, то есть налицо явление гетерохронности развития эмбрионов с самого начала эмбриогенеза. Причины и механизмы изменения темпа эмбриогенеза в пределах одной колонии птиц остаются слабоизученными до настоящего времени.

Целью нашей работы явилось изучение темпа эмбриогенеза и уровня элиминации эмбрионов сизой чайки Laruscanusв пределах колонии на территории орнитологического заказника о.Туренец(Пермский край, Ильинский район).

Материал для работы был собран в 2012-2014 гг. на о. Туренец, расположенном в Камском водохранилище. Площадь заказника составляет менее 13 га, большая часть территории занята древостоем. Гнездовое поселение сизой чайки занимало прибрежную затапливаемую полосу и небольшие поляны острова, сильно заросшие ивой, крапивой, малиной, шиповником. Численность колонии сизой чайки колебалась от 500 пар (1975 г) до 2241 пар (1986 г), в связи с зарастанием и размыванием острова число гнездящихся пар чаек стало постепенно падать. В 2012 г. зарегистрировано на острове всего 248 пар, в 2013 году около 200 пар.

При выполнении работы были использованы лабораторные и полевые методы исследования. Проводили картирование, мечение гнезда и кладки. Забор материала для вскрытия осуществляли с 10 до 12 часов дня. Зародышей фиксировали в 10\% формалине. Степень развития эмбрионов определяли по шкале для выводковых птиц В. Гамбургера и Г. Гамильтона (1951), с изменениями и дополнениями по Рагозиной (1961). Во время проведения работы кладки птиц целиком не изымались, забор материала осуществляли из разных гнезд и частей колонии (центр, периферия).

Результаты исследования. За период наблюдений в колонии отмечена разновременность начала откладки яиц. В 2012 г. первые яйца в кладках появились 29-30 апреля, в 2013 - 1-2 мая, что связано с погодными условиями (весна 2013 г. наступила позже, чем в 2012 г. и отмечалась низкими температурами). В целом, сроки яйцекладки в пределах колонии сильно растянуты и составляют 60-61 сутки, что для колониальных птиц, в целом, не характерно. Причиной этого, вероятно, является тот факт, что большая часть первых кладок была подвержена затоплению во время поднятия уровня воды в Камском водохранилище или была разорена пернатыми и наземными хищниками.Массовое вылупление птенцов в период исследования пришлось на 29 - 30 мая 2012 г, и 1-2 июня 2013 г.

Длительность инкубации и темп эмбриогенеза имели асинхронный характер в пределах колонии. Так, в 2013г вылупление из яиц, отложенных 3 мая и 8 мая в пределах колонии приходилось на одно и то же время - 29 мая. Сроки эмбрионального развития составили в среднем 26 и 21 сутки. Быстрее развивались эмбрионы из центра колонии. При определении стадий развития эмбрионов из разных частей колонии были также выявлены факты асинхронного развития (таб.1). 
Таблица 1.

Различия в темпе эмбриогенеза сизых чаек в пределах колонии

\begin{tabular}{|c|c|c|c|}
\hline \multirow{2}{*}{$N$ гнезда } & Участок колонии & $\begin{array}{c}\text { Сутки } \\
\text { инкубации }\end{array}$ & Стадия развития \\
\hline 1 & центр & 3 & 20 \\
\hline 2 & восточная периферия & 6 & 15 \\
\hline 3 & центр & 12 & 35 \\
\hline 4 & восточная периферия & 12 & 35 \\
\hline 5 & перицентр & 12 & 35 \\
\hline 6 & центр & 18 & 40 \\
\hline 7 & центр & 20 & 40 \\
\hline 8 & западная периферия & 22 & 43 \\
\hline 9 & перицентр & 22 & 35 \\
\hline 10 & центр & 24 & 42 \\
\hline 11 & центр & 24 & 43 \\
\hline 12 & центр & 24 & 44 \\
\hline 13 & центр & & $45-46$ \\
\hline
\end{tabular}

Так, 3-х суточный эмбрион из центра колонии находился на 20 стадии развития, а шестисуточный эмбрион с периферии (восточная часть колонии) - на 15 стадии. 35-ой стадии достигли в большей части колонии эмбрионы на 12-ые сутки, а в перицентре в одном гнезде только на 22 сутки. Следовательно, темп развития зародышей варьирует в пределах одной колонии. Диапауза в ходе эмбрионального развития связана с низкими температурами в начале весны. А ускорение эмбриогенеза в более поздних кладках обеспечивалось экологоэтологическими факторами (более плотным насиживанием, более равномерным и интенсивным прогревом).

При высокой степени гетерогенности темпа эмбриогенеза и продолжающейся тенденции уменьшения численности колонии сизой чайки острова Туренец, представляет интерес выяснение успешности размножения птиц в колонии. По нашим наблюдениям, 14 \% гнезд от общего количества кладок были подвержены затоплению во время поднятия уровня воды в Камском водохранилище или были разорены. Общая успешность размножения сизых чаек в колонии острова составила $45,2 \%$.

Таблица 2

Причины элиминачии и возраст погибщих эмбрионов

\begin{tabular}{|c|c|c|c|c|c|}
\hline Причины элиминации & \multicolumn{5}{|c|}{ Возраст эмбрионов, сутки } \\
\cline { 2 - 6 } & $1-2$ & 6 & 12 & 18 & 22 \\
\hline Неправильное расположение эмбриона & - & - & - & 1 & - \\
\hline Прилипание к подскорлуповой оболочке & - & 1 & - & - & - \\
\hline Нарушение целостности скорлупы & - & - & 1 & 1 & - \\
\hline Патологические отклонения в развитии & 8 & - & 1 & - & 1 \\
\hline
\end{tabular}

Эмбриональная смертность в 2012 г. составила 6,6 \%, в 2013 г.- 3,7\% от общего количества яиц. Наибольшее количество эмбрионов погибли в первые сутки эмбриогенеза. Причины элиминации эмбрионов (таб.2): неправильное расположение эмбриона в яйце (клювом к острому концу), нарушение целостности скорлуповой оболочки, прилипание желтка к подскорлуповой оболочке, замершие. Доля болтунов (неоплодотворенных) составила 0,8 \%.

На основании проведенных исследований можно сделать следующее заключение:темп эмбриогенеза сизой чайки в пределах колонии, расположенной на о.Туренец характеризуется асинхронностью. Длительность инкубации 
варьирует от 21 до 26 суток. Уровень элиминации зародышей в колонии достигает $6,6 \%$. Наиболее критический период эмбриогенеза приходится на первые сутки. Гетерохронии эмбрионального развития у сизой чайки проявляются не только в пределах одной кладки, но и в пределах всей микропопуляции (колонии острова), что обеспечивает ее фенотипическую разнородность.

\section{Литература}

1. Болотников А.М., Шураков А.И., Каменский Ю.Н., Добринский Л.Н. Экология раннего онтогенеза птиц. Свердловск: УНЦ АН СССР, 1985. $228 \mathrm{c.}$

2. Гофман Д.Н. Сходство и различия в морфогенезе зародышей птиц с разными сроками инкубации // Эволюция темпов индивидуального развития животных. М. Наука, 1977. - 244 с.

3. Рагозина М.Н. « Развитие зародыша домашней курицы в его соотношении с желтком и оболочками яйца (с таблицами последовательных стадий развития)», Москва, Издательство АН СССР, 1961.

4. Родимцев А.С. Этапность и критические периоды раннего онтогенеза птенцовых птиц / Дисс. докт. биол. наук. М., 2004. -338 с.

5. Чугайнова Л.В. Гетерохронии в формировании костного мозга и гематологических показателей в раннем онтогенезе полувыводковых и птенцовых птиц. Автореферат диссертации на соискание ученой степени кандидата биологических наук.Москва, 2005. - 17 с.

6. Шураков А.И. Типы насиживания и гетерохронность развития эмбрионов птиц // Гнездовая жизнь птиц. Пермь, 1984. С. 74-84.

7. Шураков А.И., Литвинов Н.А., Шураков С.А. О синхронности и асинхронности эмбриогенеза птиц // Электронный научный журнал «Современные проблемы науки и образования». - 2013. - №2. 